\title{
AUDIT COMMITTEE QUALITY AND FINANCIAL REPORTING IN DEPOSIT MONEY BANKS IN NIGERIA
}

Joseph U.
Madugba $^{1}$
(iD) Kerry E. Howell
(iD Tony Ikechukwu
Nwanji $^{3}$
(iD) Sainey Faye ${ }^{4}$
(iD Ben-Caleb Egbide ${ }^{5}$
(D) Damilola Felix
Eluyela $^{6+}$

Article History

Received: 12 May 2020 Revised: 23 December 2020 Accepted: 25 January 2021 Published: 19 February 2021

\section{Keywords}

Audit committe Audit committee meetings Audit committee size Corporate governance Deposit money banks Financial reporting quality.

JEL Classification: $\mathrm{M} 41 ; \mathrm{M} 42$.

\author{
${ }^{\prime}$ Lecturer in Accounting, Department of Accounting and Finance, Landmark \\ University, Nigeria. \\ Email:madugba.joseph@lmu.edu.ng.Tel: +2348063697038 \\ ${ }^{2}$ Professor of Leadership and Governance, Teesside University Business \\ School, Teesside University, United Kingdom. \\ Email:k.howell@tees.ac.ukTel:+447860853898 \\ ${ }^{s}$ Professor of Accounting, Department of Accounting and Finance, Landmark \\ University, Nigeria. \\ Email:nwanji.tony@lmu.edu.ng.Tel: +2348165555084 \\ "Associate Professor of Accounting and Finance, Department of Accounting \\ and Finance New University, Buckingham, United Kingdom. \\ Email:sainey.faye@bucks.ac.uk Tel: +447984801991 \\ ${ }_{5}^{5}$ Senior Lecturer in Accounting E Finance, Department of Accounting and \\ Finance, Landmark University, Nigeria. \\ Email:ben-caleb.egbide@lmu.edu.ng.Tel: +2348035855644 \\ ${ }^{6}$ Lecturer in Accounting, Department of Accounting and Finance, Landmark \\ University, Nigeria. \\ Email: eluyela.damilola@lmu.edu.ng Tel: +2348131399363
}

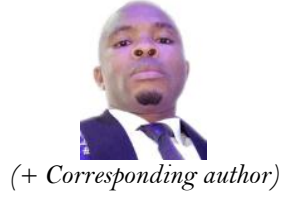

(+ Corresponding author)

\section{ABSTRACT}

The credibility of financial reporting is crucial as it assures the user of its authenticity. In this study, we examined the effect of audit committee quality on the quality of financial reporting of deposit money banks in Nigeria. A descriptive research design was adopted and secondary data sourced from annual accounts of seven deposit money banks for seven years were used to test our hypotheses. The dependent variable in this study is financial reporting quality measured with accrual model. In contrast, the independent variables are the number of members on the audit committee with accounting and finance knowledge, the size of the audit committee, the number of audit committee meetings held in a year and audit committee independence. Descriptive statistics, normality test, a multicollinearity test and regression analysis were used to examine the data. A notable outcome revealed that except for several audit committee meetings held in a given year the other independent variables were found to be insignificant and are not, therefore, determinant of financial reporting quality in deposit money banks in Nigeria. The study concluded that audit committee quality is not a determinant of financial reporting quality in deposit money banks in Nigeria and the study recommends that ability should be paramount for the appointment of members to the audit committee and advises that the audit committee should always be given adequate consideration by management in decision making.

Contribution/Originality: This study is one of very few that has investigated the effect of audit committee quality on the quality of financial reporting of deposit money banks in Nigeria using an accrual model. 


\section{INTRODUCTION}

Corporate scandal around the world has shaken the faith of the business community and has introduced investors to the quality of reporting, thus permitting corporate governance mechanisms as a subject of discussion (Al-Shaer, Salama, \& Toms, 2017; DeZoort, Hermanson, Archambeault, \& Reed, 2002; Eluyela et al., 2019a). An audit committee is a representation of shareholders that promotes the quality of reporting (Cadbury, 2000; Tricker, 2000). Owens-Jackson, Robinson, and Waller (2009) opined that the main responsibilities of an audit committee is to ensure proper reporting practices, establishment and maintenance of acceptable accounting practices. The core focus of an audit is to scrutinize the truthfulness of the financial reports produced by management. Based on current regulations and the demand for enhanced reporting, the duties of an audit committee have been expanded to include supervision of quarterly financial reports (Samuel, Mohammed, \& Ali, 2017). Owolabi and Dada (2011) asserted that the rate of liquidation has made the position of an audit committee crucial in every corporate organisation, and an audit committee is a watchdog in any corporation as they link the exterior assessor and the Board of Directors (Blue Ribbon Committee, 1999).

Well-known scandals have shredded investors' confidence in capital markets and corporate management. Regulators and professionals have traced it back to the lack of sound audit committee quality that ensures financial reporting quality (Baatwah, Ahmad, \& Salleh, 2016; Beasley, Carcello, Hermanson, \& Lapides, 2009; Dhaliwal, Naiker, \& Navissi, 2010; Krishnan \& Visvanathan, 2007). This is not ruled out in Nigeria as it motivated the government through its regulatory agencies to set up different codes of governance, but despite this, various financial scandals persist in Nigerian deposit money banks. Recently, Access Bank merged with Big Diamond Bank, which came as a shock and demands were made regarding the quality of the audit committee with regard to financial reporting in Nigeria's banks since they are meant to oversee the quality of reporting.

Moreover, investors base their expectations of future earnings on stock prices. An essential set of information investors use to form expectations of future earnings is the current accounting information; therefore, higher quality financial reporting due to the presence of a quality audit committee will put investors at ease regarding the prediction of future earnings.

Furthermore, the extent to which audit committee quality relates to financial analysts' abilities to predict prospective income more accurately, and that financial analysts represent an important and influential group of account users, it is possible that the ability of an average investor to anticipate future earnings also improves with audit committee quality (Archambeault \& DeZoort, 2001; Ashbaugh-Skaife, Collins, \& LaFond, 2006; Carcello, Hollingsworth, Klein, \& Neal, 2006). There is extant literature in Nigeria on this subject (Yadirichukwu \& Ebimobewei, 2013); (Ndubuisi \& Ezechukwu, 2017); (Nwanyanwu, 2017), but none of these studies employed the same variables or time period as this study. These lacunas motivated the urgent need to examine the effect of audit committee quality on financial reporting quality of deposit money banks in Nigeria.

\section{LITERATURE REVIEW}

An audit committee is intended to contribute to civilizing audit quality. The core assignments of this committee are to supervise both financial reporting and management to ensure that manipulation of income and supplementary bookkeeping malpractices do not occur (Arens, Elder, \& Beasley, 2009; Marx, 2008). Audit committee members' professionalism should be a vital feature for its effectiveness in satisfying the key role of ensuring audit quality (DeZoort \& Salterio, 2001). An audit committee's financial and accounting ability reduces financial restatement and any inclination of management to engage in imaginative bookkeeping (DeZoort, 1997; DeZoort et al., 2002; Kalbers \& Fogarty, 1993; Xie, Davidson III, \& DaDalt, 2003). The requirements of an audit committee include a knowledge of bookkeeping and financial reporting, internal controls and auditing, and it is expected that a committee with this knowledge will enhance higher financial reporting quality (DeZoort et al., 2002; Fama, 1980; Fama \& Jensen, 1983; Kalbers \& Fogarty, 1993; Mustafa \& Youssef, 2010). 


\subsection{Corporate Governance}

Corporate governance aims to help the board of directors through its committees to achieve effective management of the company's affairs (Eluyela et al., 2019a; Eluyela et al., 2019b). The audit committee is one of the four committees of corporate governance with responsibility for the oversight of an organisation's internal processes and works with both internal and external auditors. The current updated UK Corporate Governance Code (FRC, 2016) states that "the purpose of corporate governance is to facilitate effective, entrepreneurial and prudent management that can deliver the long-term success of the company.” The Cadbury Report, 1992 is the first version of the UK Corporate Governance Code (FRC, 2014, 2016) and paragraph 2.5 is still used as the classic definition of the context of the Code:

"Corporate governance is the system by which companies are directed and controlled. Boards of directors are responsible for the governance of their companies. The shareholders' role in governance is to appoint the directors and the auditors and to satisfy themselves that an appropriate governance structure is in place. The responsibilities of the Board include setting the company's strategic aims, providing the leadership to put them into effect, supervising the management of the business and reporting to shareholders on their stewardship. The Board's actions are subject to laws, regulations and the shareholders in general meeting." (Cadbury Report, 1992).

Corporate governance also refers to the procedures and instruments that the owners and interest groups of a company use to influence and check management decisions and processes (Okere et al., 2019). It is widely regarded as the evaluation of the performance of the executive directors of the company by, or for, the company's stakeholder groups. Nwanji and Howell (2007) pointed out that:

"Corporate governance aims to ensure that the boards of directors do their jobs properly. It also protects shareholders' rights, enhances disclosure and transparency, facilitates the effective functioning of the Board and provides an adequate legal and regulatory enforcement framework. It addresses the agency problem through a mix of the company law, stock exchange listing rules and self-regulatory codes."

Corporate governance is also about guiding management through managing the affairs of the company leading to the achievement of the companies' objectives, whether those objectives are shareholdership or stakeholdership, as long as management keeps within the rules of the game (Friedman, 1970; Nwanji \& Howell, 2005; Nwanji et al., 2020).

\subsection{Shareholdership Model}

Nwanji and Howell (2007) stated that:

"The traditional Anglo-American Model of corporate governance is based on profit maximization, which claims to protect shareholders' interests. Profit maximization concept is an offspring of the free market system. This is governed by the price mechanism. Individual entrepreneur's profit maximisation does maximize the overall economic welfare of society."

\subsection{Stakeholder Theory}

The German model considers that corporations are run in the interests of stakeholders.

"A stakeholder in an organisation is any group or individual who can affect or is affected by the achievement of the organisation's objectives" (Freeman, 1984). The shareholder, by contributing to the corporation's capital, faces more risk than other stakeholders. However, in a corporate context, a stakeholder is entitled to consideration similar to that of a shareholder. Phillips (2003) claims that the stakeholder theory is a theory of organisational management and ethics and it is distinct because it addresses morals and values explicitly as a central feature of managing organisations. 


\subsection{Stakeholders' Claim on Organisation Wealth}

Table 1 shows the claim from a company's wealth. All stakeholders in the group are the first to receive their rewards from the profits, while the shareholders, who are owners of the business, pick up whatever is left, which may be profits or losses; they bear the highest risk when the company is not doing well and receive the greatest reward when the company is prospering.

Table 1. Stakeholders group and their reward

\begin{tabular}{l|l|l}
\hline Stakeholders & Reward & Contribution \\
\hline Employees & Paid by salaries and wages & Work and provision of services \\
\hline Creditors & Paid by debutantes & Suppliers of goods and services \\
\hline Financiers & Collected interest on loans & Loans and financial services \\
\hline Government & Paid corporation taxes & Enabling environment \\
\hline Management & Salaries and bonuses & Managing and leadership \\
\hline Customer & Goods and services & Purchase of goods and services \\
\hline Communities & $\begin{array}{l}\text { Through corporate social } \\
\text { responsibility (CSR) }\end{array}$ & Provide a place for business \\
\hline Shareholders & Profit/dividend or loss & Provide capital shares \\
\hline
\end{tabular}

\subsection{The Global Stakeholdership of Corporation}

Nwanji and Howell (2005) stated that.

"Since 2000, most multinational corporations in the UK and the US closed their call centres and other service operations and moved the jobs to India and other Asian countries, thereby creating global stakeholder groups - the workers and the communities in those countries. However, what happened to the stakeholder groups who lost their jobs in developed countries? HSBC Bank said it has local global stakeholders in those countries in which it operates."

Good corporate governance is essential for the success of an organisation. Overall, the issue of corporate governance is focused on shareholder vs stakeholder theories and which of them is better for managing the affairs of the corporation (GCGC, 2016). Correct corporate governance code pressures on UK boards of directors to take corporate conduct seriously have grown in recent years. They range from new legislation and increased employee requirements to media reports of corporate misconduct and the growth of socially responsible investment (SRI). Corporate values and ethics must come from the top and board involvement is vital for the effectiveness of an ethics policy. Shareholders elect the board of directors to represent their interests and interests of all stakeholders as there is a public expectation for the board to cover all viewpoints. A study of shareholder proposals showed that $43.3 \%$ of all proposals were considered for a vote (Sternberg, 2004). Regarding corporate governance proposals, $49.2 \%$ were voted on and $35.2 \%$ were omitted or withdrawn, $31.4 \%$ of social policy proposals were voted on and $61.6 \%$ were omitted or withdrawn.

\subsection{The Responsibility of the Board of Directors}

Figure 1 presents the board of directors' responsibilities; first is the monitoring duty that allows the board to deal with problems of corporate governance. External control devices, such as hostile takeovers, have multiplied because of the failure of boards. The composition of the board includes external directors (those without extensive ties to the company). External directors enhance the viability of the board and reduce collusion. Hermalin and Weisbach (2007) stated that the market views the appointment of an outsider to a CEO position more favorably than an insider-boards with external directors are more likely to appoint an outsider as CEO. Compensation of board members: Director stock ownership better aligns director interests with stockholders. 


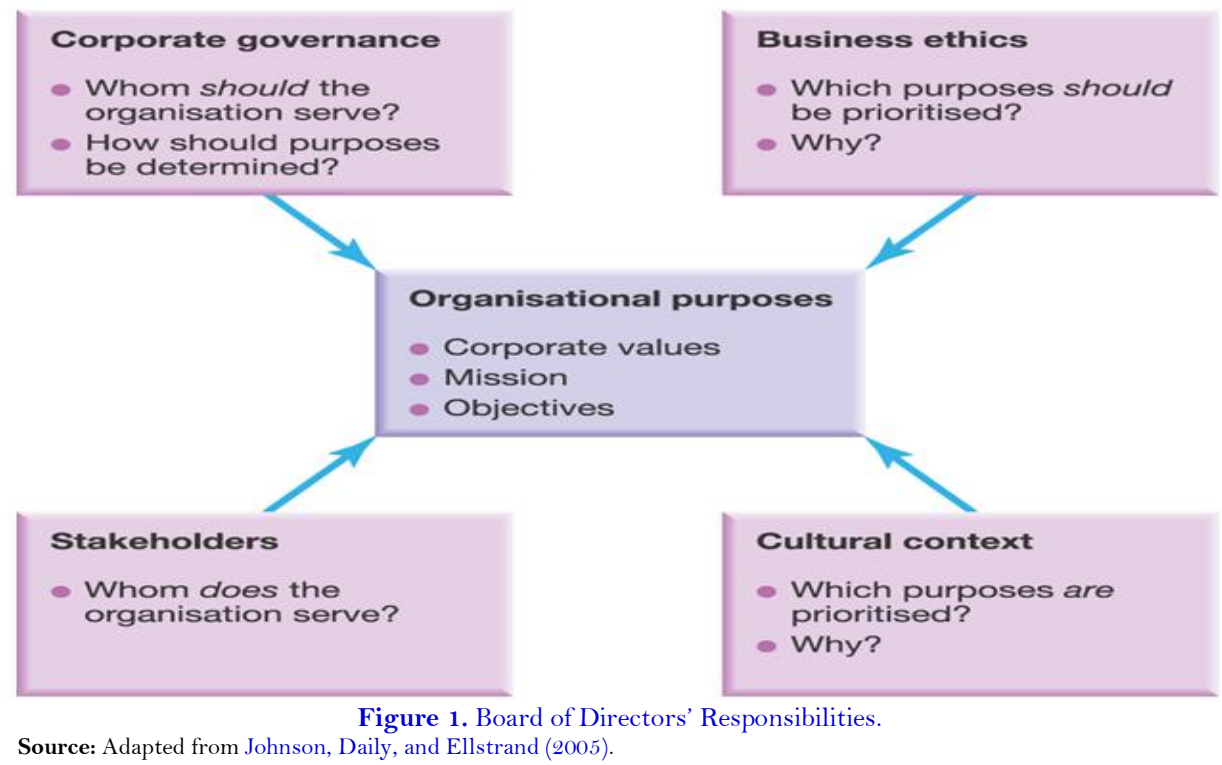

Stock ownership requirements for directors and payment of part or all the annual retainer in stock and stock options. Nwanji et al. (2019) stated that:

"Finance directors' retirements with stock studies find directors of top-performing companies hold a greater number of shares than do counterparts at poor-performing firms. Critics argue that compensation should not be a motivating factor. Numerous possibilities for board rating: CEO performance, strategic plans, outside directors, election processes, firm performance, etc. Scandals expose possible improvements: more power to shareholders, director votes disclosed."

A better board rating by CalPERS (based on independence and performance) is associated with a higher spread of return on invested capital (ROIC) over the cost of capital. Spin-offs are associated with better internal governance and control practices (Mitlak, 2016).

\subsection{Financial Reporting Quality}

Several definitions of financial reporting quality exist in prior literature; among them are the studies of Chalaki, Didar, and Riahinezhad (2012) who opined that it is the accuracy of the communication of financial dealings. Financial reporting is a medium through which the accountability of stewardship is made to shareholders and stakeholders of organisations. Adebayo (2005) asserted that it is a coordinated manner through which managers give accounts of operations to owners of corporations. He also stated that every financial report should clearly show resources (obtained and existing), the manner in which they are used and results of such operations. However, it is crucial to state that the focus of financial reporting or statement is to communicate to the shareholders and other stakeholders what resources have been acquired and how they are applied to generate a result which defines their return and assist them in making informed economic decisions.

The core aims of financial reporting quality may be divided into two: To aid investment decision making and management accountability. This is because investors need financial information to predict which investment will yield the highest return with a manageable level of risk. Investments return forms of dividends and capital appreciation or depreciation, and in the evaluation of investment opportunities investors examine the quality and authenticity of a business' future performance and hence their approximations of expected yields in dividends and assets increase. Financial reports are also used in a broader sense to determine management's ability to harness the resources committed to them in running the enterprise (Eluyela et al., 2020b). This is because management is not only responsible to owners of a business for guardianship and safety of enterprise resources but much more for their competent and gainful use and for shielding them from adverse economic conditions. Organisation performance is 
comprehensive and covers issues based on efficiency and effectiveness. One core solution to ensure proper accounting reporting quality is the ability of accountants to abide by the ethics of the profession.

In this study, financial reporting quality was measured using the accrual method.

The accrual model measures the extent of earnings management under existing legislation. The theorist believes that earnings are the most crucial in organisations, and when it is negatively affected the company's performance will be affected. Thus, it is calculated as:

$$
\Delta \mathrm{WCit}=\mathrm{CFOit}-1+\mathrm{CFOit}+\mathrm{CFOit}+1+\Delta \mathrm{REVit}+\mathrm{PPEit}+\varepsilon
$$

$\Delta \mathrm{WC}=$ the change in working capital accruals or current accruals from the statement of cash flows.

$\mathrm{CFO}=$ the cash flows from operating activities.

$\triangle \mathrm{REV}=$ change in revenue.

$\mathrm{PPE}=$ property, plant and equipment.

\subsection{Empirical Review}

In their study, Raweh, Kamardin, and Malik (2019) found a positive association between the audit committee and financial reporting lag, which showed that audit committee ability reduces financial reporting lag. Ohaka and Abio (2018), in a study on an aluminum corrugating firm in Rivers State, Nigeria, concluded that a positive and significant relationship exists between audit committee independence and financial reporting quality; Oji and Ofoegbu (2017) found that qualifications are paramount in the appointment of committee members; and Al-Shaer et al. (2017) asserted that proper quality disclosure is displayed by companies with a quality audit committee, while audit committee quality does not show increased disclosure.

Umobong and Ibanichuka (2017) also found a positive association between audit committee ability and financial reporting quality based on the results of a study on a food and beverage firms in Nigeria. This is supported by the studies of Baatwah et al. (2016) and Kibaya, Ahmed, and Amaran (2016), who agree that the ability of an audit committee prejudices quality reporting. Kamolsakulchai (2015) stated that there is a positive relationship between audit committee effectiveness and financial reporting quality, meaning that audit committee effectiveness improves the reporting quality of firms listed on the stock exchange of Thailand.

\subsection{Theoretical Framework}

Behavioral Decision Theory: This theory posits that cognitive and psychomotor skills are a necessity for the determination of ability. It also states that ability should be considered in terms of an individual's ability to reason well. Therefore, this study will adopt this theory since the audit committee quality and ability to function is based on reasoning (cognitive) and following defined regulations.

\section{METHODOLOGY}

A descriptive research design was used because data relating to both the dependent and independent variables already exist in literature and is not subject to manipulation by the researcher. DeZoort et al. (2002) adopted the same in a similar study. Secondary data were extracted from published annual accounts of the deposit money banks in this study (Ozordi, Adetula, Eluyela, Aina, \& Ogabi, 2019; Ozordi, Eluyela, Uwuigbe, Uwuigbe, \& Nwaze, 2020). The time frame covered is from 2013 to 2019 and data from seven banks were used. The justification of this time frame is determined by the post-IFRS (International Financial Reporting Standards) period in Nigeria. The dependent variable in this study is financial reporting quality measured by the accrual model, and the independent variables are quality of audit committee measured by members of the audit committee with accounting and finance knowledge, size of the audit committee (number of members sitting on the board (SFAC)), number of meetings held in a year and audit committee independence measured by the ratio of non-executive to executive directors. 
Descriptive statistics, a normality test, a multicollinearity test and regression analysis were all conducted with the aid of SPSS v23 (Ozordi et al., 2020; Umukoro, Eluyela, Ozordi, Inua, \& Balogun, 2020).

\subsection{Model Specification}

Models 1 and 2 stated were adopted from the study by Madugba et al. (2020).

$$
\begin{gathered}
\mathrm{FRQ}=\left(\mathrm{MAFK}_{\mathrm{it}}, \mathrm{SFAC}_{\mathrm{it}}, \mathrm{NM}_{\mathrm{it}}, \mathrm{ACI}_{\mathrm{it}}\right) \\
\mathrm{FRQ}=\left(\beta \mathrm{O}+\beta_{1} \mathrm{MAFK}+\beta_{2} \mathrm{SFAC}+\beta_{3} \mathrm{NM}+\beta_{4} \mathrm{ACI}+\mathrm{et}\right)
\end{gathered}
$$

Where FRQ = financial reporting quality measured with the accrual model, MAFK = members of the audit committee with accounting and finance knowledge, SFAC $=$ size of audit committee, $\mathrm{NM}=$ number of audit committee meetings held in a year and ACI = audit committee independence.

\section{RESULTS AND DISCUSSION}

4.1. Descriptive Statistics of the Variables

Table 2. Descriptive Statistics.

\begin{tabular}{c|c|c|c|c|c}
\hline \multirow{2}{*}{} & $\mathbf{N}$ & Minimum & Maximum & Mean & Std. Deviation \\
\cline { 2 - 6 } & Statistic & Statistic & Statistic & Statistic & Statistic \\
\hline LFRQ & 49 & 11.56 & 13.96 & 12.6594 & .73976 \\
\hline MAFK & 49 & 1.00 & 6.00 & 3.4898 & 1.00255 \\
\hline SFAC & 49 & 4.00 & 6.00 & 5.6735 & .55482 \\
\hline NM & 49 & 4.00 & 6.00 & 5.0816 & .75930 \\
\hline ACI & 49 & 1.50 & 4.00 & 2.5041 & .69160 \\
\hline Valid N (listwise) & 49 & & & & \\
\hline
\end{tabular}

Table 2 presents descriptive statistics for all variables (Ezenwoke, Efobi, Asaleye, \& Felix, 2020). Financial reporting quality, as shown in Table 2 , has minimum and maximum values of 11.56 and 13.96, respectively. A mean value of 12.6594 and standard deviation of .73976 were also reported for financial reporting quality of the deposit money banks in our study. Members of the audit committee with accounting and finance knowledge (LMAFK) were shown to have minimum and maximum values of 1.00 and 6.00, respectively. Also, a positive mean value of 3.4898 with a standard deviation value of 1.00255 was also reported for members of the audit committee with accounting and finance knowledge. The size of the audit committee (LSFAC) showed minimum and maximum values of 4.00 and 6.00, respectively. A positive mean value of 5.6735 was reported for the size of the audit committee with a standard deviation of .55482. Several audit committee meetings held in a year reported minimum and maximum values of 4.00 and 6.00, respectively. A mean value of 5.0816 was reported, which is positive, with a standard deviation value of .75930. Audit committee independence showed minimum and maximum values of 1.50 and 4.00 , respectively. The mean value for audit committee independence is 2.5041 , with a standard deviation value of .69160 .

\subsection{Test for Normality}

A normality test (see Table 3) was conducted with the aid of Kolmogorov-Smirnov and Shapiro-Wilk tests and Figure 2 shows the histogram. The Kolmogorov-Smirnov test results showed a statistic value of 0.118 and a probability value of 0.086 , which is not too far from the point of zero but is higher than 0.05 , which means that the data is typically distributed. The Shapiro-Wilk test indicated a test statistic of 0.936 with a probability value of 0.010 , which is not higher than 0.05, but the Kolmogorov-Smirnov test and the histogram, which is relatively bellshaped, indicate that the data is relatively customarily distributed (see Figure 2). 
Table 3. Normality Test

\begin{tabular}{c|c|c|c|c|c|c}
\hline \multicolumn{4}{c}{ SHOWING TESTS OF NORMALITY } \\
\hline & \multicolumn{3}{|c}{ Kolmogorov-Smirnov } & \multicolumn{3}{c}{ Shapiro-Wilk } \\
\cline { 2 - 7 } & Statistic & df & Sig. & Statistic & df & Sig. \\
\hline LFRQ & 0.118 & 30 & $0.086^{*}$ & 0.936 & 30 & 0.010 \\
\hline
\end{tabular}

*. This is a lower bound of real significance.

a. Lilliefors significance correction.

\subsection{Histogram Showing Normality Test}

Figure 2 presents the histogram showing the normality test. The mean score is 12.66, while the standard deviation is 0.74 from 49 items; this shows that the variables are normally distributed.

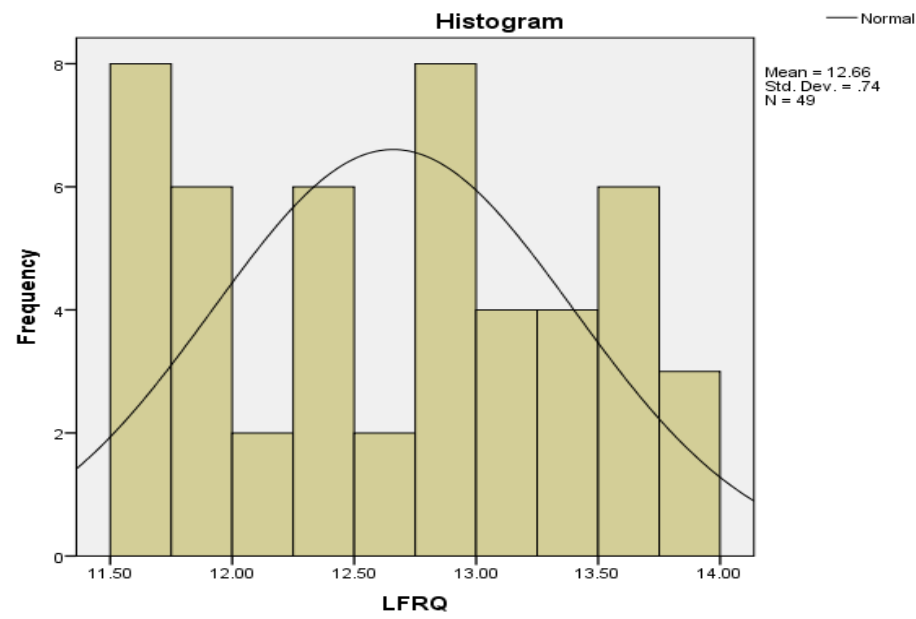

Figure 2. Histogram showing normality test.

\subsection{Test for Outliers}

The test for outliers was also conducted using a boxplot, and Figure 3 shows that there are no outliers capable of disrupting our result, hence we continued with the test of collinearity.

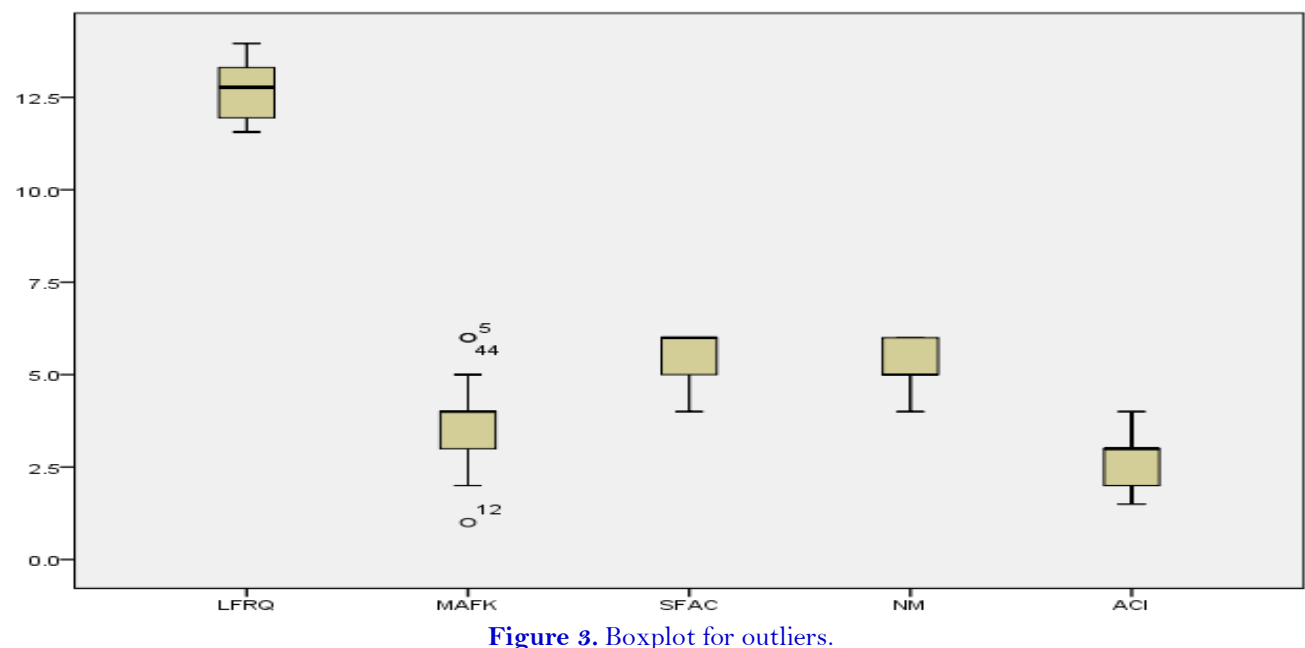

\subsection{Multicollinearity Test}

Tolerance and variance inflation factor (VIF) were adopted to test the threat of multicollinearity between the independent variables. 
Table 4. Multicollinearity Test

\begin{tabular}{c|c|c}
\hline Variable & Tolerance & Variance inflation factor (VIF) \\
\hline LMAFK & 0.958 & 1.044 \\
\hline LSFAC & 0.905 & 1.105 \\
\hline LNM & 0.966 & 1.035 \\
\hline ACI & 0.938 & 1.053 \\
\hline
\end{tabular}

As contained in Table 4, the tolerance values of $0.958,0.905,0.966$ and 0.938 are less than 0.10 , indicating that we have not violated the multicollinearity assumptions. This means that there is no collinearity between the independent variables in our study and this is corroborated by the variance inflation factor (VIF) values of 1.044, $1.105,1.035$ and 1.053, which are far below the cut-off of 10 .

\subsection{Test of Hypothesis}

The relationship between members of the audit committee with accounting and finance knowledge, size of the audit committee, number of meetings in a year, and audit committee independence with financial reporting quality of deposit money banks in Nigeria is not significant.

Decision rule: Accept null hypothesis if the probability value computed by SPSS is greater than or equal to $0.05(\mathrm{P} \leq 0.05)$.

\subsection{Multiple Regression Results}

Table 5. Multiple Regression Test

\begin{tabular}{l|c|c|c|c}
\hline Variable & Coefficient B & Coefficient Beta & t-statistics & Sig. \\
\hline Constant & 13.672 & -0.052 & 10.498 & 0.000 \\
\hline MAFK & -0.038 & 0.166 & -0.372 & 0.712 \\
\hline SFAC & 0.222 & -0.426 & 1.168 & 0.248 \\
\hline NM & -0.415 & -0.011 & -3.090 & 0.003 \\
\hline ACI & -0.012 & & -0.078 & 0.938 \\
\hline R & 0.437 & & & \\
\hline R2 & 0.191 & & & \\
\hline Adj. R2 & 0.118 & & & \\
\hline F-Statistics & 2.602 & & & \\
\hline Probability & 0.049 & & & \\
\hline
\end{tabular}

a. Dependent variable: FRQ.

b. Predictors (Constant): MAFK, SFAC, NM, ACI

Table 5 shows that the coefficient of determination value of 0.191 , means $19.1 \%$. The coefficient of multiple determination of 0.118 is also shown. This implies about $11.8 \%$ of the total changes seen in the tested variable (financial reporting quality (FRQ)) is influenced by the predictor variables (MAFK, STAC, NM and ACI) in our study, whereas $88.2 \%$ was caused by other variables other than the ones in this study. The F-statistic value of 2.602 confirms the fitness of model specification.

However, only one out of the three variables was found to be significant. Therefore, we rejected the null hypothesis and concluded that the relationship between the quality of the audit committee and financial reporting quality in deposit money banks in Nigeria is not significant.

\subsection{Discussion of Results}

Evidence from Table 5 shows that members of the audit committee with accounting and finance knowledge have a regression coefficient value of -.038. This value is negative and insignificant, which means that the influence of members of the audit committee with accounting and finance knowledge on financial reporting quality in deposit money banks in Nigeria is insignificant. 
This, however, is without prejudice regarding whether this factor is considered in the selection of audit committee members, the degree of knowledge of such members and the extent of their contributions if put into practice. This finding disagrees with Oji and Ofoegbu (2017) even though their study was also conducted in Nigeria and on the same sector, but the years studied differ.

Table 5 illustrates the influence, or perhaps the contribution, of the size of the audit committee on financial reporting quality of deposit money banks in Nigeria. It shows that SFAC has zero influence on FRQ as confirmed by a regression coefficient value of .222 .

However, this value is definite but insignificant; size is just a number and does not determine experience or skill, and this finding does not corroborate the studies of Raweh et al. (2019). The latter study was not based in Nigeria and did not consider the size of the audit committee as a variable.

Some meetings held by the audit committee in the year is showed to have a regression coefficient value of -.415. This value is negative but significant, implying that the number of meetings held is a determinant of financial reporting quality in deposit money banks in Nigeria.

This finding is without prejudice regarding the issue's discussion, the outcome of meetings held and whether recommendations of the board are implemented or not. The audit committee that often meets without making a significant contribution to the financial reporting of any firm. This finding is supported by the study of Umobong and Ibanichuka (2017).

Statistical evidence from Table 5 supports the theory that audit committee independence has a negative and insignificant association with financial reporting quality of deposit money banks in Nigeria, as shown with a regression coefficient value of -.012. This means that degree of independence of the audit committee is microscopic and cannot be relied upon to explain the credibility of financial reporting in deposit money banks. Our finding disagrees with the study of Raweh et al. (2019), which was not in Nigeria, and the study of Ohaka and Abio (2018) in Nigeria which was based on aluminum corrugating companies in Rivers State.

\section{CONCLUSION}

In this study, we examined the effect of the quality of audit committee and financial reporting quality in deposit money banks in Nigeria. Specifically, we assessed how members of the audit committee with accounting and finance knowledge, size of the audit committee, number of the meeting held by the audit committee in a year and audit committee independence impact financial reporting quality. The tested variable of financial reporting quality was measured with an accrual model.

However, our findings revealed that except for some audit committee meetings held in a given year, other variables have an insignificant effect on financial reporting quality. This finding implies that knowledge, ability, contributions and independence of audit committee members is minute and cannot influence the financial reporting quality. Therefore, we conclude that the quality of the audit committee is not a significant determinant of the financial reporting quality of deposit money banks in Nigeria.

\section{RECOMMENDATIONS}

From the findings and conclusions of this study, we recommend the following:

1. An appropriate number of experts should be included in audit committees.

2. The number of audit committee members should be increased urgently in all deposit money banks in Nigeria.

3. Audit committees should hold meetings at regular intervals.

4. Expertise should be paramount for appointment into audit committees and advice offered by the audit committee should always be given adequate consideration by management in decision making.

5. The number of non-executive directors should be higher than that of executive directors, as this will help to prevent independence of the audit committee. 
Funding: This study received no specific financial support.

Competing Interests: The authors declare that they have no competing interests.

Acknowledgement: All authors contributed equally to the conception and design of the study.

\section{REFERENCES}

Adebayo, A. (2005). Financial reporting: An aid to efficient economic management in the public sector. The Nigerian Accountant, 38(1), 33-38.

Al-Shaer, H., Salama, A., \& Toms, S. (2017). Audit committees and financial reporting quality: Evidence from UK environmental accounting disclosures. Journal of Applied Accounting Research, 18(1), 2-21.Available at: https://doi.org/10.1108/jaar10-2014-0114.

Archambeault, D., \& DeZoort, F. T. (2001). Auditor opinion shopping and the audit committee: An analysis of suspicious auditor switches. International Journal of Auditing, 5(1), 33-52.Available at: https://doi.org/10.1111/1099-1123.00324.

Arens, A. A., Elder, R. J., \& Beasley, M. S. (2009). Auditing and assurance services: An integrated approach (13th ed.). New Jersey: Prentice-Hall.

Ashbaugh-Skaife, H., Collins, D. W., \& LaFond, R. (2006). The effects of corporate governance on firms' credit ratings. Journal of Accounting and Economics, 42(1-2), 203-243.

Baatwah, S. R., Ahmad, N., \& Salleh, Z. (2016). Audit committee financial expertise and financial reporting timeliness in emerging market: Does audit committee chair matter? Issues in Social and Environmental Accounting, 10(4), 63-85.

Beasley, M., Carcello, J., Hermanson, D., \& Lapides, P. (2009). Fraudulent financial reporting: Consideration of industry traits and corporate governance mechanisms. Accounting Horizons, 14(4), 441-454.

Blue Ribbon Committee. (1999). Report and recommendation of a blue-ribbon committee on improving the effectiveness of corporate audit committee. Business Lawyer, 54(2), 106-1095.

Cadbury, A. (2000). Global corporate governance forum: World Bank (pp. 1-44). The International Bank for Reconstruction and Development/THE WORLD BANK 1818 H Street, N.W. Washington, D.C. 20433, U.S.A.

Cadbury Report. (1992). The cadbury committee report - European corporate governance institute. Retrieved from http://www.ecgi.org/codes/documents/cadbury.pdf_br.

Carcello, J. J. V., Hollingsworth, C. C. W., Klein, A., \& Neal, T. L. (2006). Audit committee financial expertise, competing for corporate governance mechanisms, and earnings management. SSRN Electronic Journal, 6(1), 1-55.

Chalaki, P., Didar, H., \& Riahinezhad, M. (2012). Corporate governance attributes and financial reporting quality: Empirical evidence from Iran. International Journal of Business and Social Science, 3(15), 223-229.

DeZoort, F. (1997). An investigation of audit committees' oversight responsibilities. Abacus, 33(2), 208-227.Available at: https://doi.org/10.1111/1467-6281.00012.

DeZoort, F. T., Hermanson, D., Archambeault, D., \& Reed, S. (2002). Audit committee effectiveness: A synthesis of the empirical audit committee literature. Journal of Accounting Literature, 21(1), 38-75.

DeZoort, F. T., \& Salterio, S. E. (2001). The effects of corporate governance experience and financial-reporting and audit knowledge on audit committee members' judgments. Auditing: A Journal of Practice \& Theory, 20(2), 31-47.Available at: https://doi.org/10.2308/aud.2001.20.2.31.

Dhaliwal, D., Naiker, V., \& Navissi, F. (2010). The association between accruals quality and the characteristics of accounting experts and mix of expertise on audit committees. Contemporary Accounting Research, 27(3), 787-827.Available at: https://doi.org/10.1111/j.1911-3846.2010.01027.x.

Eluyela, D. F., Adetula, D. T., Obasaju, O. B., Ozordi, E., Akintimehin, O., \& Popoola, O. (2019a). Foreign directors, indigenous directors and dividend payout structure in Nigerian deposit money banks. Banks and Bank System, 14(2), 1-14.Available at: https://dx.doi.org/10.21511/bbs.14(2).2019.16.

Eluyela, D. F., Olajide, D., Tolase, O. A., Okere, W., Ogabi, M., \& Kafidipe, A. (2019b). Impact of gender dich otomy on dividend payout policy in listed Nigerian financial services firm. Cogent Business and Management, 6, 1-10.Available at: https://doi.org/10.1080/23311975.2019.1687270. 
Eluyela, D. F., Okere, W., Otekunrin, A. O., Okoye, J. N., Asamu, F., \& Ajetunmobi, O. (2020b). Institutional investors ownership and financial performance: Examining the nexus in Nigerian deposit money banks. Research in World Economy, 11(6), 177-184.Available at: https://doi.org/10.5430/rwe.v11n6p177.

Ezenwoke, O. A., Efobi, U. R., Asaleye, A. J., \& Felix, D. E. (2020). The determinants of undergraduate accounting students' early participation in professional examinations. Cogent Education, 8(1), 1815962.Available at: https://doi.org/10.1080/2331186X.2020.1818411.

Fama, E. F. (1980). Agency problems and the theory of the firm. Journal of Political Economy, 88(2), 288-307.

Fama, E. F., \& Jensen, M. C. (1983). Separation of ownership and control. The Journal of Law and Economics, 26(2), 301-325.

FRC. (2014). UK corporate governance code. London: (C) The Financial Reporting Council FRC.

FRC. (2016). UK corporate governance code. London: (C) The Financial Reporting Council FRC.

Freeman, E. (1984). Strategic management: A stakeholder approach. Boston: Pitman Press.

Friedman, M. (1970). The social responsibility of business is to increase its profits - the New York Times Magazine. Reprinted by Permission of The New York Times Syndicate, Paris, France.

GCGC. (2016). Good corporate governance code (GCGC) (C) the financial reporting council limited. The Financial Reporting Council Limited Registered in England number 2486368. Registered London Wall, London EC2Y 5AS.

Hermalin, B. E., \& Weisbach, M. S. (2007). Transparency and corporate governance. Retrieved from http://www.ssrn.com/abstract=958628.

Johnson, J., Daily, C., \& Ellstrand, A. (2005). Boards of directors: A review and research agenda. Journal of Management, 22(3), 409-438.

Kalbers, L., \& Fogarty, T. (1993). Audit committee effectiveness: An empirical investigation of the contribution of power. Auditing: A Journal of Practice \& Theory, 12(1), 24-49.

Kamolsakulchai, M. (2015). The impact of the audit committee effectiveness and audit quality on financial reporting quality of listed company in stocks exchange of Thailand. Review of Integrative Business Eீ Economics Research, 4(2), 328-341.

Kibaya, M. U., Ahmed, A. C., \& Amaran, N. A. (2016). Audit committee characteristics and financial reporting quality in Nigerian nonfinancial listed firm. Paper presented at the The European Proceedings of Social and Behavioural Sciences. EPSBS, International.

Krishnan, G. V., \& Visvanathan, G. (2007). Reporting internal control deficiencies in the post-Sarbanes-Oxley era: The role of auditors and corporate governance. International Journal of Auditing, 11(2), 73-90.Available at: https://doi.org/10.1111/j.1099-1123.2007.00358.x.

Madugba, J. U., Ben-Caleb, E., Okpe, I., Fadoju, O. S., Ben-Caleb, J. O., \& Mbamara, K. I. (2020). Risk management committee, financial reporting quality and financial performance of deposit money banks in Nigeria. Research in World Economy, 11(5), 288-296.Available at: https://doi.org/10.5430/rwe.v1 1n5p288.

Marx, B. (2008). An analysis of the development, status and functioning of the audit committee at large listed companies in South Africa. Unpublished PhD Thesis The University of Johannesburg.

Mitlak, A. S. N. (2016). An investigation into the effect of corporate governance on audit quality in developing markets: Evidence from Jordan. Doctoral Thesis, Durham University UK.

Mustafa, S., \& Youssef, N. B. (2010). Audit committee financial expertise and misappropriation of assets. Managerial Auditing Journal, 25(3), 208-225.Available at: https://doi.org/10.1108/02686901011026323.

Ndubuisi, A. N., \& Ezechukwu, B. O. (2017). Determinants of audit quality: Evidence from deposit money banks listed on Nigeria Stock Exchange. International Journal of Academic Research in Accounting, Finance and Management Sciences, 7(2), 117130.Available at: https://doi.org/10.6007/ijarafms/v7-i2/2877.

Nwanji, T. I., \& Howell, K. E. (2007). Shareholdership, stakeholdership and the modern global business environment: A survey of the literature. Journal of Interdisciplinary Economics, 18(4), 347-361.Available at: https://doi.org/10.1177/02601079x07001800406. 
Nwanji, T. I., \& Howell, K. E. (2005). The stakeholder theory in the modern global business environment. International Journal of Applied Institutional Governance, 1(1), 1-12.

Nwanji, T. I., Howell, K. E., Faye, S., Otekunrin, A. O., Eluyela, D. F., Lawal, A. I., \& Eze, S. C. (2020). Impact of foreign direct investment on the financial performance of listed deposit banks in Nigeria. International Journal of Financial Research, 11(2), 323-347.Available at: https://doi.org/10.5430/ijfr.v11n2p323.

Nwanji, T. I., Howell, K. E., Faye, S., Agba, D. Z., Adewara, S. O., Lawal, A. I., \& Eluyela, F. (2019). Assessment of the effectiveness of ethical corporate governance in corporate decision-making: A grounded theory approach. Archives of Business Research, 7(1), 147-168.Available at: https://doi.org/10.14738/abr.11.5836.

Nwanyanwu, L. A. (2017). Audit quality practices and financial reporting in Nigeria. International Journal of Academic Research in Accounting, Finance and Management Sciences, 7(2), 145-155.Available at: https://doi.org/10.6007/ijarafms/v7-i2/2879.

Ohaka, J., \& Abio, I. T. (2018). Audit committee independence and corporate financial reporting quality in aluminum corrugating companies in rivers state. International Journal of Economics and Financial Management, 3(1), 2545-9566.

Oji, O., \& Ofoegbu, G. N. (2017). Effect of audit committee qualities on financial reporting of listed companies in Nigeria: A perspective study. International Journal of Scientific and Research Publications, 7(10), 278-290.

Okere, W., Eluyela, D. F., Lawal, A. I., Ibidunni, O., Eseyin, O., Popoola, O., \& Awe, T. (2019). Foreign expatriates on board and financial performance: A study of listed deposit money banks in Nigeria. The Journal of Social Science Research, 5(2), 418423.Available at: https://doi.org/10.32861/jssr.52.418.423.

Owens-Jackson, L. A., Robinson, D., \& Waller, S. S. (2009). The association between audit committee characteristics, the contracting process and fraudulent financial reporting. American Journal of Business, 24(1), 57-66.Available at: https://doi.org/10.1108/19355181200900005.

Owolabi, S. A., \& Dada, S. O. (2011). Audit committee: An instrument of effective corporate governance. European Journal of Economics, Finance and Administrative Sciences, 35(35), 174-183.

Ozordi, E., Adetula, D. T., Eluyela, D. F., Aina, A., \& Ogabi, M. (2019). Corporate dynamism and cash holding decision in listed manufacturing firms in Nigeria. Problems and Perspectives in Management, 17(4), 1-12.Available at: http://dx.doi.org/10.21511/ppm.17(4).2019.01.

Ozordi, E., Eluyela, D. F., Uwuigbe, U., Uwuigbe, O. R., \& Nwaze, C. E. (2020). Gender diversity and sustainability responsiveness: Evidence from Nigerian fixed money deposit banks. Problems and Perspectives in Management, 18(1), 119-129.Available at: https://dx.doi.org/10.21511/ppm.18(1).2020.11.

Phillips, R. (2003). Stakeholder theory and organisational ethics. San Francisco. Mallin C: BK Berrett-Koehler Publishers Inc.

Raweh, N. A. M., Kamardin, H., \& Malik, M. (2019). Audit committee characteristics and audit report lag: Evidence from Oman. International Journal of Accounting and Financial Reporting, 9(1), 152-169.Available at: https://doi.org/10.5296/ijafr.v9i1.14170.

Samuel, E. A., Mohammed, M., \& Ali, M. (2017). Audit committee effectiveness of financial reporting quality in listed companies in Nigeria stock exchange. International Journal of Academic Research in Business and Social Sciences, 7(6), 487505.Available at: https://doi.org/10.6007/ijarbss/v7-i6/3006.

Sternberg, E. (2004). Corporate governance: Accountability in the marketplace (2nd ed.). London: IEA, The Institute of Economic Affairs.

Tricker, B. (2000). Corporate governance-the subject whose time has come. Corporate Governance: An International Review, 8(4), 289-296.Available at: https://doi.org/10.1111/1467-8683.00207.

Umobong, A. A., \& Ibanichuka, E. (2017). Audit committee attributes and financial reporting quality of food and beverage firms in Nigeria. International Journal of Innovative Social Sciences and Humanities Research, 5(2), 1-13.

Umukoro, O. E., Eluyela, D. F., Ozordi, E., Inua, O. I., \& Balogun, S. B. (2020). Nollywood accounting and financial performance: Evidence from Nigerian cinemas. International Journal of Financial Research, 11(2), 271-280.Available at: https://doi.org/10.5430/ijfr.v1 1n2p271. 
Xie, B., Davidson III, W. N., \& DaDalt, P. J. (2003). Earnings management and corporate governance: The role of the board and the audit committee. Journal of Corporate Finance, 9(3), 295-316.Available at: https://doi.org/10.1016/so9291199(02)00006-8.

Yadirichukwu, E., \& Ebimobewei, A. (2013). Audit committee and timeliness of financial Reports: Empirical evidence from Nigeria. Journal of Economics and Sustainable Development, 2(1), 25 -36.

Views and opinions expressed in this article are the views and opinions of the author(s), Asian Economic and Financial Review shall not be responsible or answerable for any loss, damage or liability etc. caused in relation to/arising out of the use of the content. 